PONTIFÍCIA UNIVERSIDADE CATÓLICA do RIO dE JANEIRO

\title{
A EVOLUÇÃO DA SAÚDE FINANCEIRA DOS GRANDES BANCOS EM UM PERÍODO DE GRANDES INOVAÇÕES
}

Pedro Henrique Surette Bastos

Trabalho de Conclusão de Curso

Centro de ciências socials - CCS

Departamento de Administração

Graduação em Administração de Empresas 


\section{A EVOLUÇÃO DA SAÚDE FINANCEIRA DOS GRANDES BANCOS EM UM PERÍODO DE GRANDES INOVAÇÕES}

Trabalho de Conclusão de Curso, apresentado ao programa de graduação em Administração da PUC-Rio como requisito parcial para a obtenção do título de graduação em Administração.

Orientadora: Liana Ribeiro 


\section{Resumo}

BASTOS, Pedro Henrique Surette. A evolução da saúde financeira dos grandes bancos em um período de grandes inovações. Rio de Janeiro, 2021. 19 p. Trabalho de Conclusão de Curso - Departamento de Administração. Pontifícia Universidade Católica do Rio de Janeiro.

Este trabalho tem como objetivo estudar a evolução da saúde financeira dos maiores bancos brasileiros em um período de grandes inovações no mercado bancário. A pesquisa utilizou como base os dados divulgados no sistema IF Data do Banco Central do Brasil, coletando os dados das 5 maiores instituições prudenciais em quantidade de ativos. Os dados foram tratados e expostos em forma de gráficos para embasar a análise feita. Foi possível concluir que os grandes conglomerados financeiros possuem uma alta capacidade de se adaptar financeiramente às mudanças em seu ambiente competitivo.

\section{Palavras-chave}

saúde financeira; retorno sobre o ativo; liquidez; margem líquida; alavancagem financeira; bancos; inovação; adaptabilidade; contabilidade.

\section{Abstract}

BASTOS, Pedro Henrique Surette. The evolution of the financial health of major banks in a period of major innovations. Rio de Janeiro, 2021. 19 p. Trabalho de Conclusão de Curso - Departamento de Administração. Pontifícia Universidade Católica do Rio de Janeiro.

This paper aims to study the evolution of the financial health from the largest Brazilian banks in a period of great innovations in the banking market. The data used were published at the IF Data system from Central Bank of Brazil's website, collecting financial information from the 5 largest prudential institutions in terms of assets. The data was treated and displayed in the form of graphics to support the analysis made. It was possible to conclude that large financial conglomerates have a high capacity to financially adapt to changes in their competitive environment. 


\section{Key-words}

saúde financeira; retorno sobre o ativo; liquidez; margem líquida; alavancagem financeira; bancos; inovação; adaptabilidade; contabilidade. 


\section{Sumário}

1 O tema e o problema de estudo 1

1.1 Contextualização 1

1.2 Problematização 2

1.3 Objetivo final 3

1.4 Objetivos intermediários 3

1.5 Foco do estudo 3

1.6 Relevância do estudo 3

2 Referencial teórico 5

2.1 Bancos 5

2.1.1 Bancos de câmbio 5

2.1.2 Bancos comerciais 5

2.1.3 Bancos de investimento 5

2.1.4 Bancos de desenvolvimento 6

2.1.5 Bancos múltiplos 6

2.2 Demonstrativos Financeiros 6

2.2.1 Balanço Patrimonial (BP) 6

2.2.2 Demonstração de Resultado do Exercício (DRE) 7

$\begin{array}{ll}2.3 \text { Indicadores Financeiros } & 7\end{array}$

$\begin{array}{ll}2.3 .1 \mathrm{ROA} & 7\end{array}$

2.3.2 Margem Líquida $\quad 7$

2.3.3 Índice de Liquidez Imediata 8

2.4 Índice de Basileia 8

2.5 Índice de Imobilização 9

3 Metodologia de pesquisa 10

$\begin{array}{ll}3.1 \text { Coleta dos dados } & 10\end{array}$

$\begin{array}{ll}3.2 \text { Tratamento dos dados } & 10\end{array}$

4 Análise dos resultados $\quad 11$

$\begin{array}{ll}4.1 \text { Rentabilidade } & 11\end{array}$

$\begin{array}{ll}4.2 \text { Margens } & 14\end{array}$ 
$\begin{array}{ll}4.3 \text { Liquidez Imediata } & 17\end{array}$

4.4 Índice de Basileia $\quad 21$

4.5 Índice de imobilização 23

5 Conclusão 25

6 Referências Bibliográficas $\quad 27$ 


\section{Lista de Gráficos}

Gráfico 1 - Evolução do ROA médio 10

Gráfico 2 - Evolução do lucro líquido médio 11

Gráfico 3 - Evolução do ativo total médio 11

Gráfico 4 - Evolução do ROA estratificado por instituição 12

Gráfico 5 - Evolução do lucro líquido estratificado por instituição 13

Gráfico 6 - Evolução do ativo total estratificado por instituição 14

Gráfico 7 - Evolução da margem líquida média 14

Gráfico 8 - Evolução da receita total média $\quad 15$

Gráfico 9 - Evolução da margem líquida estratificada por instituição 15

Gráfico 10 - Evolução da receita total estratificada por instituição 16

Gráfico 11 - Evolução da liquidez imediata média 17

$\begin{array}{ll}\text { Gráfico } 12 \text { - Evolução do ativo circulante médio } & 17\end{array}$

$\begin{array}{ll}\text { Gráfico } 13 \text { - Evolução do passivo circulante médio } & 18\end{array}$

Gráfico 14 - Evolução da liquidez imediata estratificada por instituição 18

$\begin{array}{ll}\text { Gráfico } 15 \text { - Evolução do ativo circulante estratificado } & 19\end{array}$

Gráfico 16 - Evolução do passivo circulante estratificado 19

Gráfico 17 - Evolução do índice de Basileia médio 20

Gráfico 18 - Evolução do índice de Basileia estratificado 21

Gráfico 19 - Evolução do índice de imobilização médio 22

Gráfico 20 - Evolução do índice de imobilização estratificado 23 


\section{0 tema e o problema de estudo}

\subsection{Contextualização}

O Sistema Financeiro Nacional, segundo o Banco Central (BCB, 2021), é resultado da formação de todas as empresas que prestam o serviço de intermediação financeira, essas que promovem a liquidez entre os tomadores e os credores, as duas pontas fundamentais em uma economia. $O$ bom desenvolvimento e funcionamento desse sistema é algo extremamente importante para qualquer país, sendo ele responsável por viabilizar veículos de crédito, investimento e de seguros, fazendo assim com que a economia como um todo continue girando.

Ainda de acordo com o BC, um dos integrantes do SFN são os bancos e as caixas econômicas. Nesse grupo, existem os chamados bancos tradicionais, sendo eles bancos múltiplos que possuem uma alta participação de mercado. Segundo Aline Bronzati (2020), os cinco maiores bancos brasileiros detêm mais de 7,3 trilhões de reais sob forma de ativos, sendo que o total de ativos no mesmo período representava 10,5 trilhões de reais. Isso faz com que essas instituições detenham cerca de 69,5\%, sendo assim um mercado concentrado nas mãos de poucos players.

Por mais que esse setor ainda seja muito concentrado, o setor bancário atravessou por diferentes ondas de inovação. De acordo com o professor Michael Porter (1986), quando um ambiente competitivo é formado por empresas cujos produtos ou serviços possuem um maior grau de imitabilidade, os players necessitam constantemente de atualizar suas estratégias e criar vantagens competitivas perante seus concorrentes. Isso acaba sendo visível no setor bancário, tendo em vista que os grandes players oferecem produtos e serviços parecidos, fazendo com que a inovação seja um dos principais caminhos para criar a vantagem competitiva necessária. $O$ mobile e internet banking, pagamentos via NFC, APIs, PIX, surgimento de fintechs e criptomoedas são apenas alguns exemplos que surgiram e ganharam força no setor bancário no século atual.

Todas as inovações apresentadas levantaram muitas teses otimistas de investidores. Segundo uma pesquisa realizada pela Fidelity (2021) com 
investidores institucionais espalhados pela Europa, Ásia e Estados Unidos, revelou que $70 \%$ desses investidores possuem o interesse em investir em ativos digitais, mostrando que essa tecnologia ganhou muita tração por parte de grandes players globais. Além disso, essas transformações no mercado bancário geram muitos questionamentos acerca da continuidade do status quo para os bancos tradicionais, gerando preocupação por parte deles. Roberto Setubal, expresidente do Itaú Unibanco, evidenciou essa preocupação em uma reunião com analistas de mercado quando disse:

Estamos vivendo um mundo em grande transformação. Não temos resposta para o que queremos e isso nos angustia toda noite... Fintechs estão batendo na nossa porta todo dia. Estamos discutindo bastante isso no banco (SETUBAL, 2019).

\subsection{Problematização}

Apesar de todas as inovações citadas, é possível observar uma grande reação por parte dos bancos tradicionais. Na fala da Paula Sayão (2020), diretora de negócios digitais do Banco do Brasil, foi dito que o banco está com um posicionamento mais voltado em formar parcerias com as fintechs do que de fato competir diretamente, inclusive podendo trazer essas soluções advindas das startups para o portfólio de serviços do banco.

Além disso, empresas como o Bradesco e o Itaú criaram hubs de inovação, sendo, respectivamente, a Habitat e o Cubo, que buscam realizar investimentos em startups e inovações que podem aumentar a eficiência dos serviços financeiros. Todas essas iniciativas mostram que essas instituições, por mais que tiveram o seu ambiente competitivo sendo alterado, estão empenhando esforços em realizar altíssimos investimentos para acompanhar as tendências de mercado.

Não apenas isso, segundo Alberto Amparo (2020), analista da casa de análise Suno Research, os bancos tradicionais são máquinas geradoras de dinheiro e ainda possuem muitas vantagens em comparação com as fintechs. Além disso, ele ainda afirma:

Apesar da competição com as fintechs, eles ainda têm muitas vantagens. Entre elas, a escala, a eficiência e a capacidade de captar dinheiro no mercado a um custo mais baixo que o das instituições menores (AMPARO, 2020). 
Com esses pontos levantados, ainda não se tem uma resposta clara acerca dos reais impactos financeiros que essas inovações causaram nos bancos tradicionais, sendo algo ainda muito debatido.

\subsection{Objetivo final}

Tendo em vista tal debate, essa pesquisa terá como objetivo principal estudar os reais impactos na saúde financeira dos grandes bancos durante esse período de muitas inovações no mercado financeiro, marcado principalmente pela entrada de novos players digitais.

\subsection{Objetivos intermediários}

Ao estudar os impactos econômicos e financeiros ocasionados nos grandes conglomerados financeiros, será possível observar os efeitos que as inovações tecnológicas podem gerar na saúde financeira das instituições financeiras em um determinado mercado.

\subsection{Foco do estudo}

Para tal estudo, serão analisadas as alterações das principais margens, evolução dos índices de rentabilidade, liquidez, Basileia e imobilização. Além disso, também será estudado o comportamento das principais linhas de receitas e despesas dos principais bancos.

A análise será feita para os seguintes bancos: Itaú Unibanco, Banco do Brasil, Caixa Econômica Federal, Bradesco e Santander. A escolha dessas instituições foi decorrente a alta similaridade de atuação, por serem consolidados bancários e pertencerem ao mesmo segmento da resolução $n^{\circ} 4.553 / 2017$, além de serem os maiores conglomerados prudenciais em ativo total do segmento entre os anos de 2010 e 2020.

\subsection{Relevância do estudo}

Esse estudo poderá proporcionar uma visão acerca da evolução da saúde financeira dos grandes players do mercado bancário brasileiro em anos de fortes inovações tecnológicas. Os dados do estudo vão poder auxiliar em pesquisas acerca da resiliência que essas empresas possuem em momentos de muita disrupção. 


\section{Referencial teórico}

\subsection{Bancos}

De acordo com o Banco Central (2021), um banco é uma organização, pública ou privada, que é especializada em intermediar recursos entre os entes superavitários e os deficitários, além de realizar a custódia desses bens. Essas entidades também acabam oferecendo outros serviços financeiros que são derivados de sua função principal, como investimentos, empréstimos, saques, planejamento financeiro etc.

A capacidade de uma instituição em oferecer esses serviços vai depender diretamente do tipo de banco que ela se enquadra. Ainda segundo o Banco Central (2021), existem 5 tipos: Banco de câmbio; Banco comercial; Banco de desenvolvimento; Banco de investimento; Banco Múltiplo.

\subsubsection{Bancos de câmbio}

Os bancos de câmbio, como o próprio nome sugere, são responsáveis por realizar trocas entre diferentes moedas estrangeiras. Nesse tipo de instituição, os clientes podem realizar compras e vendas de pares de moedas, sendo cobrados por um spread para cada operação.

\subsubsection{Bancos comerciais}

Já os bancos comerciais, são capazes de realizar depósitos à vista e a prazo, oferecendo serviços de saque, empréstimos e custódia. Esses bancos são uma das principais fontes de liquidez para o financiamento de curto a médio prazo para a população e empresas.

\subsubsection{Bancos de investimento}

Os bancos de investimento, diferentemente dos comerciais, não oferecem o serviço de depósito à vista e conta corrente. Eles têm o foco em oferecer empréstimos, leasing e capital de giro para empresas, tendo assim operações voltadas para o longo prazo. 


\subsubsection{Bancos de desenvolvimento}

Os bancos de desenvolvimento possuem um foco em financiar projetos de médio e longo prazo, visando proporcionar o desenvolvimento econômico e social.

\subsubsection{Bancos múltiplos}

Os bancos múltiplos, diferentemente de todos os demais, acumulam mais do que apenas uma função, tendo assim múltiplas carteiras em seu portfólio. No entanto, para que seja considerado como tal, é necessário que uma de suas carteiras seja a de banco comercial ou de investimento.

\subsection{Demonstrativos Financeiros}

De acordo com o megainvestidor multibilionário Warren Buffett (2003), a contabilidade é a linguagem dos negócios. É através dela que uma empresa expressa o funcionamento e as limitações dela, sendo algo extremamente fundamental para analisar qualquer negócio. Conforme disse Rodrigo Wainberg (2018), analista da Suno Research, os demonstrativos financeiros são relatórios contábeis essenciais não apenas para os investidores tomarem decisões embasadas, mas também para os controladores e administradores acompanharem os seus esforços gerenciais sendo expressos em resultados reais na companhia.

\subsubsection{Balanço Patrimonial (BP)}

Segundo a definição de Stephen Ross, "O balanço patrimonial é uma representação do valor contábil de uma empresa em uma data específica, como se a empresa estivesse momentaneamente congelada" (ROSS, 2015, p. 22).

Nesse demonstrativo, é evidenciado a situação patrimonial da empresa, descrevendo quais bens, direitos e obrigações ela possui. Na terminologia contábil, os bens e direitos são denominados de "ativos" e as obrigações são chamadas de "passivos". Para Ross, "O balanço patrimonial declara o que a empresa possui e como ela é financiada" (ROSS, 2015, p. 22). 


\subsubsection{Demonstração de Resultado do Exercício (DRE)}

De acordo com Stephen Ross "Enquanto o balanço patrimonial é como um momento congelado, a demonstração de resultados é como uma gravação em vídeo do que as pessoas fizeram entre dois momentos" (ROSS, 2015, p. 22).

A DRE, diferentemente do BP, possui a finalidade de mostrar como foi o desempenho financeiro de uma empresa em um determinado período. Nela, serão evidenciadas as fontes de receita e de despesa que a companhia incorreu, sendo possível calcular quanto de lucro ou prejuízo ela teve nesse mesmo período.

\subsection{Indicadores Financeiros}

Segundo Stephen Ross (2015), os indicadores financeiros ajudam a expandir a compreensão sobre as principais informações presentes nos demonstrativos financeiros. Além disso, os indicadores auxiliam na comparação entre empresas diferentes, tendo em vista que eles uniformizam as demonstrações em números comparáveis.

\subsubsection{ROA}

De acordo com Ross (2015), o Return on Assets (ROA) é um indicador que mede a relação do lucro líquido contábil com o total de ativo que a companhia possui. Para calculá-lo, basta dividir o lucro líquido do período pelo ativo total da empresa em questão.

Essa medida terá como principal finalidade analisar o grau de rentabilidade de cada instituição, observando a evolução da eficiência na geração de lucros a partir do que a mesma empresa possui de ativo sob controle.

\subsubsection{Margem Líquida}

Por definição do mesmo autor (ROSS, 2015), a margem líquida estuda o quanto que determinada empresa conseguiu reter de lucro líquido contábil em sua operação. É calculada através da divisão do lucro líquido pelo total de receita líquida obtida em um determinado exercício.

Tal indicador será importante para estudar a evolução do grau de competitividade no setor e lucratividade das empresas, já que mercados mais 
competitivos acabam ocasionando em maiores brigas por preços e reduções de lucros, reduzindo assim as margens das empresas.

\subsection{3 Índice de Liquidez Imediata}

Segundo Ross (2015), a liquidez corrente é a razão entre o ativo circulante e o passivo circulante de uma determinada empresa, descontando os estoques. Em outras palavras, ele olha a relação de bens e direitos que podem ser convertidos em caixa em um período de até 12 meses com as obrigações que possuem o vencimento para o mesmo período.

O estudo da liquidez corrente acaba sendo importante para se analisar a capacidade da empresa tem em cobrir as obrigações que ela tem em um curto prazo de tempo.

No contexto bancário, a liquidez imediata tem um enfoque mais crítico. Segundo Maria José Villaça (1969), um banco possui liquidez quando possui capacidade de ter ativos que facilmente podem ser convertidos em caixa para atender a pedidos de resgates por parte dos clientes. Para ter uma boa gestão de liquidez, se faz necessário ter uma reserva de ativos para se prevenir de resgates inesperados.

Para esse estudo, será utilizado as contas de "disponibilidades" e "aplicações interfinanceiras de liquidez" como ativos imediatos e a conta de "depósito total" como passivo de curto prazo para o calculo da liquidez imediata.

\section{4 Índice de Basileia}

De acordo com o BCB (2021), o índice de Basileia é usado para fortalecer as instituições financeiras e gerar capacidade para elas absorverem choques sistêmicos e evitar eventual efeito dominó. Ele é o principal indicador utilizado para avaliar o nível de endividamento e o grau de alavancagem financeira de um banco.

Esse indicador segue os padrões estabelecidos nos acordos Basileia I, Basileia II e Basileia III, sendo que em cada acordo foi sendo consideradas novas variáveis e o cálculo foi se tornando mais refinado. Esse indicador é gerado através da razão entre o Patrimônio de Referência e o RWA, sigla em inglês para Risk-Weighted Assets, utilizada para se referir aos ativos ponderados pelo risco. 


\section{5 Índice de Imobilização}

Segundo com o Banco Central do Brasil (2001), o índice de imobilização de uma determinada instituição financeira reflete o quão comprometido o patrimônio líquido ajustado está com ativos imobilizados.

Conforme a resolução $\mathrm{CMN} \mathrm{n}^{\circ}$ 2669, de 25 de dezembro de 1999, o limite máximo desse indicador é de $60 \%$, sendo impedido para qualquer instituição trabalhar em um patamar a cima do estabelecido 


\section{Metodologia de pesquisa}

\subsection{Coleta dos dados}

Para viabilizar esse estudo, serão utilizadas como base os principais demonstrativos financeiros das instituições financeiras analisadas. Segundo a resolução CMN 4818 artigo $2^{\circ}$, as instituições autorizadas a funcionar pelo BC são obrigadas a divulgar as demonstrações financeiras da companhia, sendo elas: O balanço patrimonial, demonstração do resultado, demonstração do resultado abrangente, demonstração do fluxo de caixa e a demonstração da mutação do patrimônio líquido.

Todas essas informações estão disponíveis de forma pública, podendo ser acessadas no site IF.data do Banco Central. Para essa monografia, serão utilizados os dados do balanço patrimonial e da demonstração do resultado dos Conglomerados Financeiros e Instituições Individuais.

O presente estudo possui um período de análise entre os anos de 2010 e 2020. Esse período se inicia no primeiro trimestre do primeiro ano até o quarto trimestre do último ano, totalizando 44 trimestres.

\subsection{Tratamento dos dados}

Após obter os dados trimestrais, eles foram agrupados por ano para que seja possível visualizar a evolução anual dos indicadores financeiros. No caso da demonstração de resultado, os valores anuais são resultados pela soma dos valores trimestrais, enquanto os valores anuais para o balanço patrimonial são iguais ao fechamento do quarto trimestre do respectivo ano.

Os tratamentos dessas informações foram feitos através da linguagem de programação Python, utilizando as bibliotecas Pandas e Numpy. Os gráficos apresentados também foram produzidos pela mesma linguagem de programação, usando a biblioteca Matplotlib. 


\section{Análise dos resultados}

\subsection{Rentabilidade}

Ao analisar o ROA médio, é possível observar um padrão na maioria das instituições analisadas. No gráfico 1 é exposto a evolução da média desse indicador ao longo dos anos:

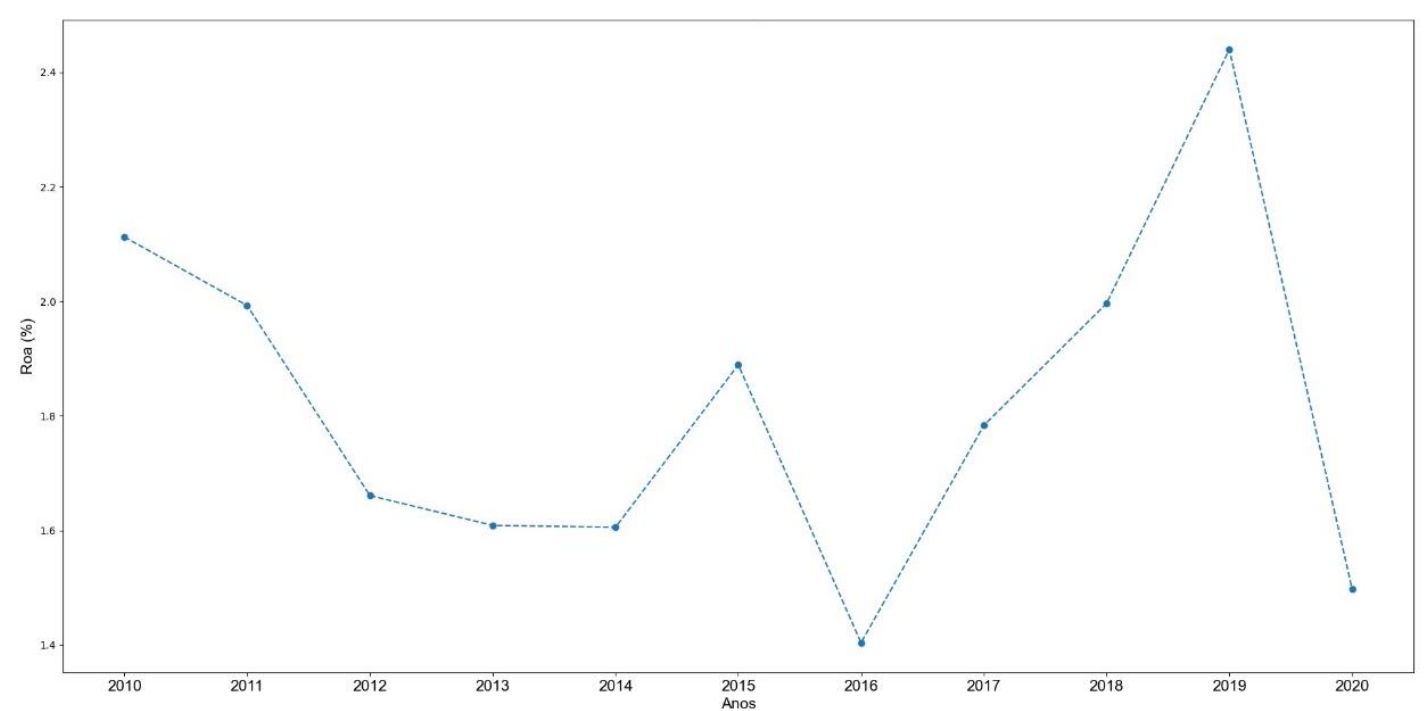

Gráfico 1 - Evolução do ROA médio Fonte: Elaborado pelo autor, 2021.

De maneira geral, é notável que a rentabilidade das instituições aumentou até o ano de 2019. Durante esse período, a rentabilidade acabou sendo acompanhada pelo movimento do lucro líquido, enquanto os ativos totais crescem constantemente ano após ano.

Já no último ano de análise, o nível de rentabilidade média das empresas caiu consideravelmente. Isso se deu por conta da queda do lucro líquido, acompanhada pelo aumento dos ativos totais presentes no balanço das instituições. Os gráficos 2 e 3 apresentam a evolução do lucro líquido e ativos totais médios das empresas ao longo dos anos: 


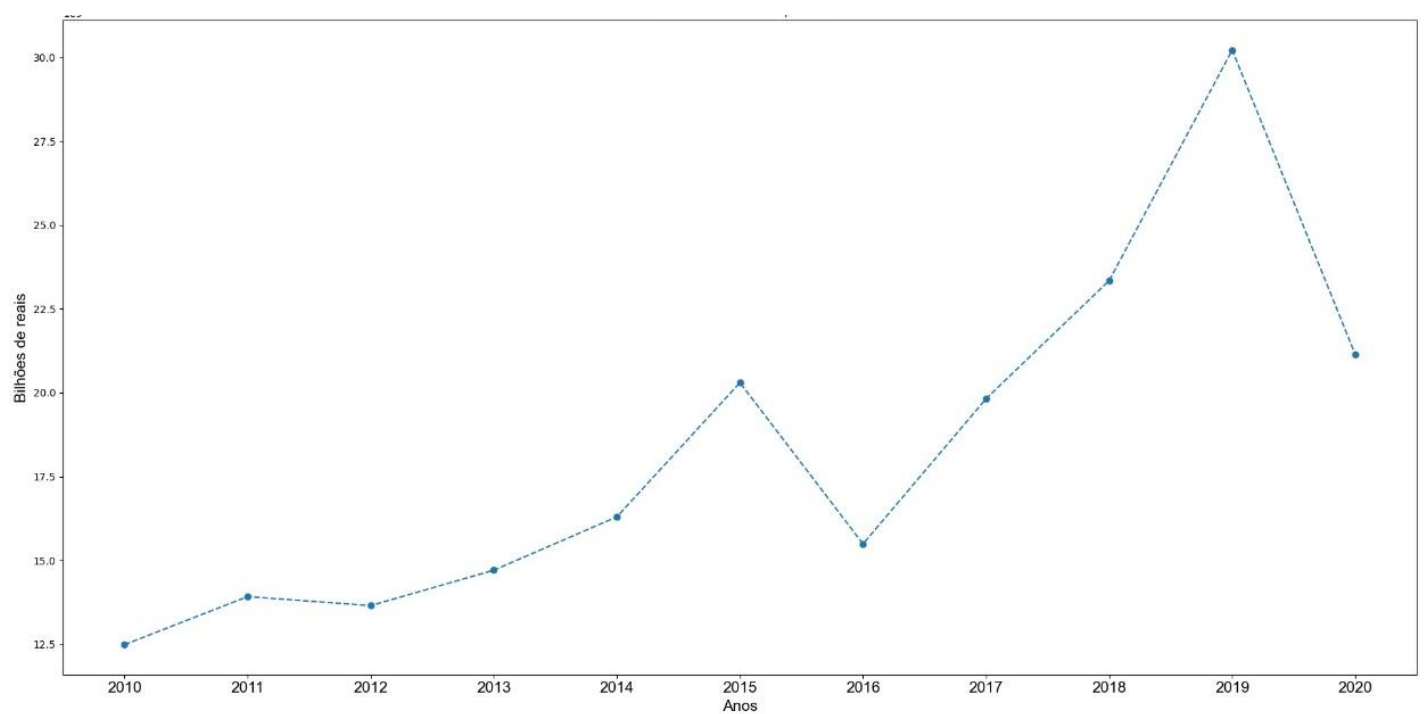

Gráfico 2 - Evolução do lucro líquido médio Fonte: Elaborado pelo autor, 2021.

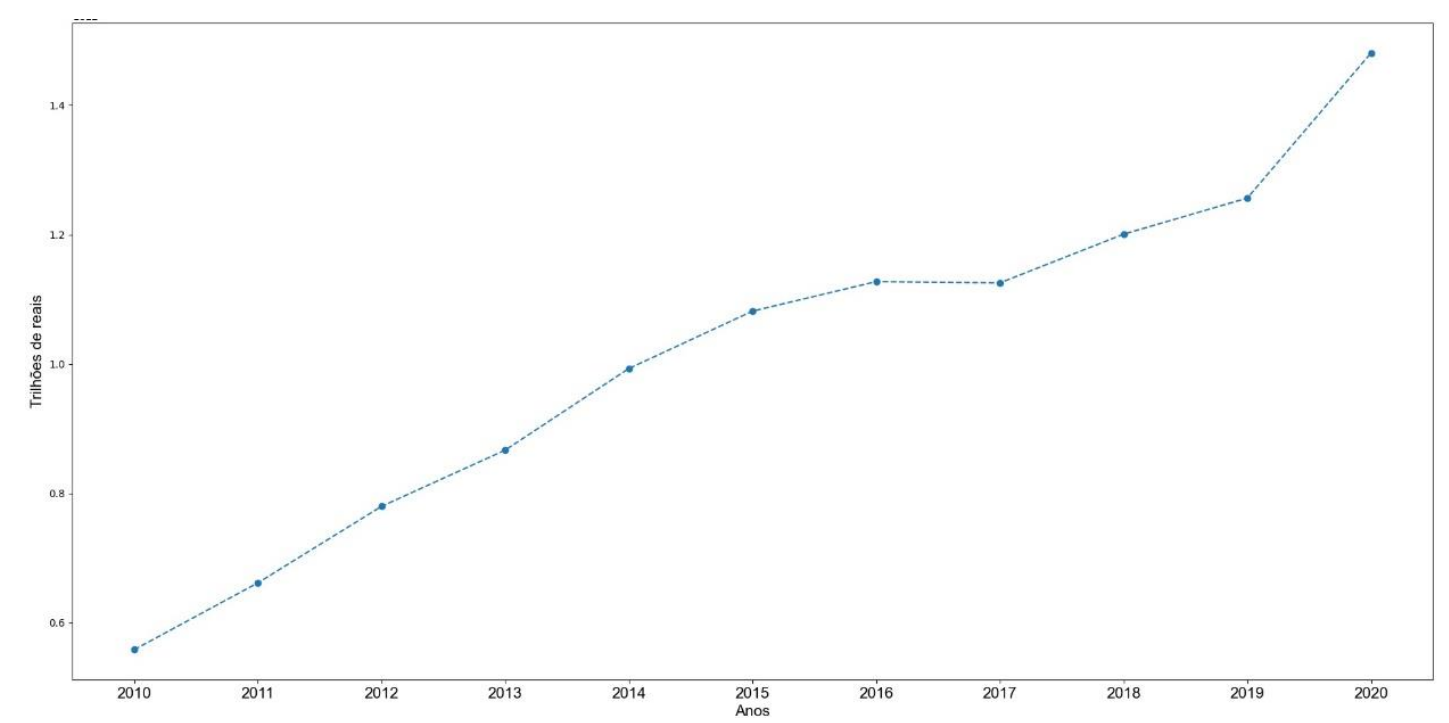

Gráfico 3 - Evolução do ativo total médio Fonte: Elaborado pelo autor, 2021.

Passando para uma análise micro, o gráfico 4 mostra a evolução do ROA de forma estratificada, fazendo com que o desempenho de cada instituição seja descriminado: 


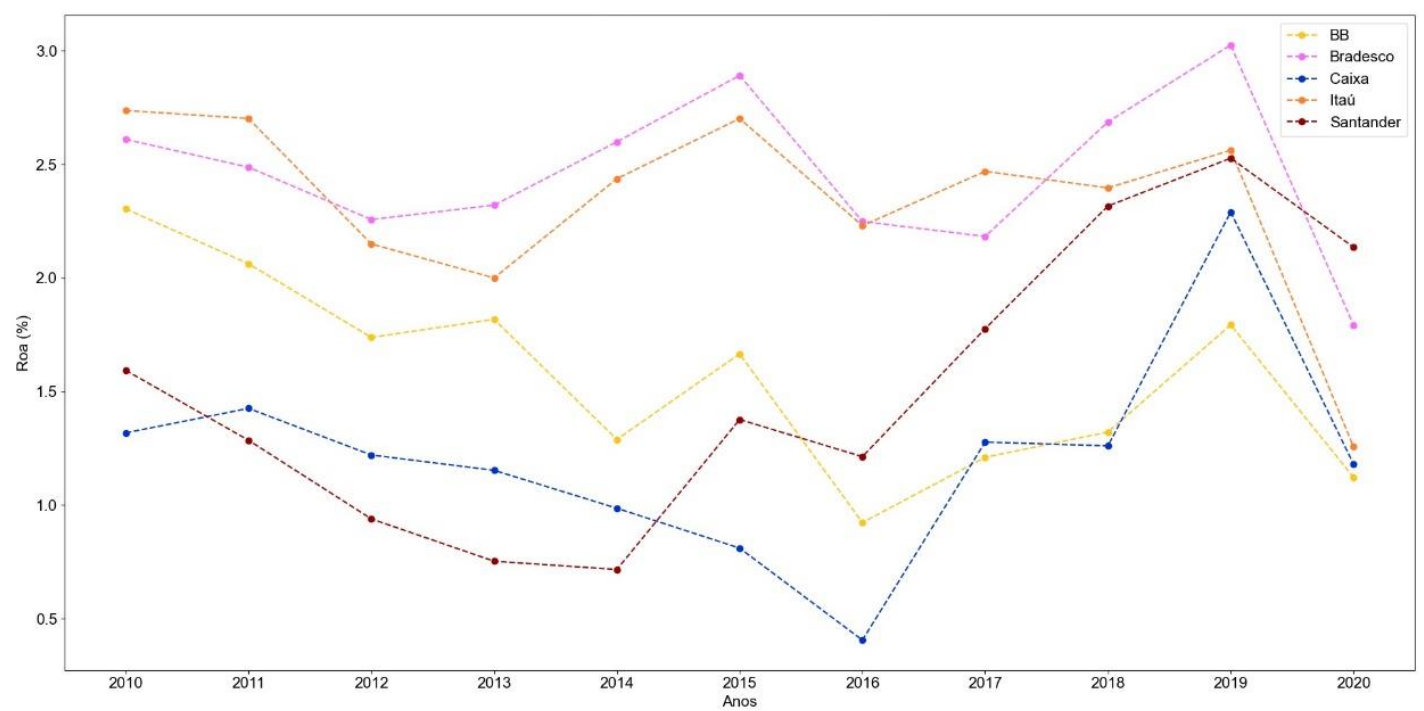

Gráfico 4 - Evolução do ROA estratificado por instituição Fonte: Elaborado pelo autor, 2021.

Das 5 empresas analisadas, 3 tiveram um aumento em sua rentabilidade até o ano de 2019, com um destaque para a Caixa Econômica Federal e para o Santander, que cresceram $73,76 \%$ e $58,63 \%$ respectivamente nesse mesmo período.

Por mais que o Itaú e Banco do Brasil apresentaram uma redução em suas rentabilidades, esse movimento não foi sinônimo de diminuição dos lucros. Assim como pode ser observado no gráfico 5 , onde é mostrado a evolução do lucro líquido de cada player, o lucro de todas as instituições apresentou um aumento até o ano de 2019, incluindo os bancos que tiveram uma redução do ROA.

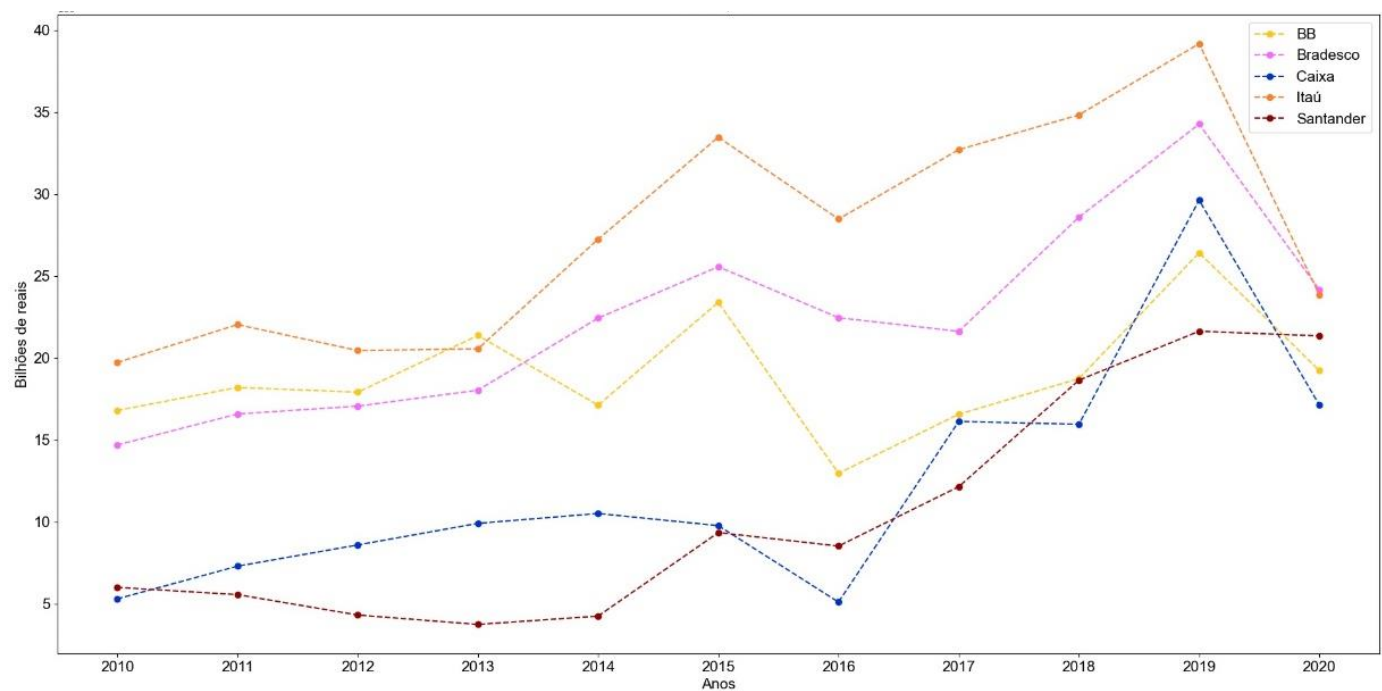

Gráfico 5 - Evolução do lucro líquido estratificado por instituição Fonte: Elaborado pelo autor, 2021. 
No entanto, ao analisar a evolução do ativo total das empresas apresentado no gráfico 6 , é possível observar que essas duas instituições financeiras tiveram um crescimento mais intenso de seus ativos em comparação aos seus lucros.

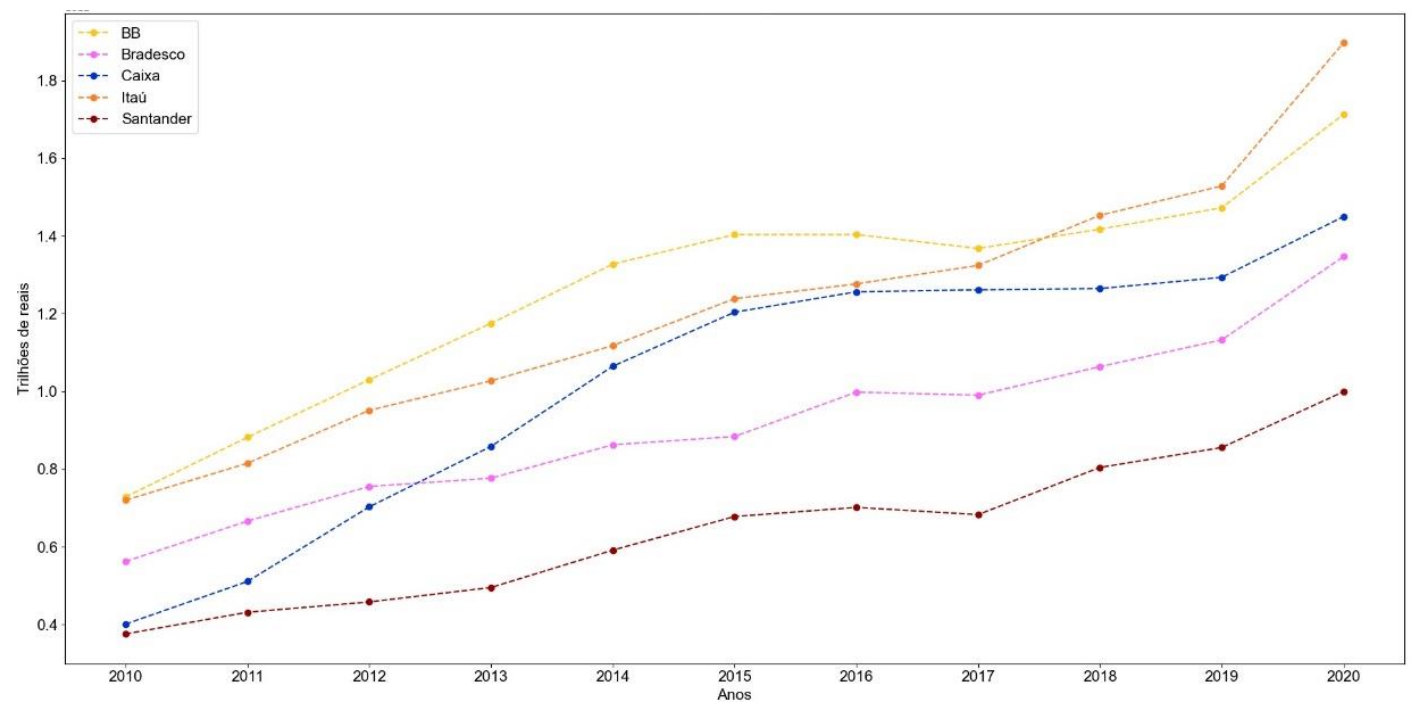

Gráfico 6 - Evolução do ativo total estratificado por instituição Fonte: Elaborado pelo autor, 2021.

No caso do Itaú, o crescimento médio composto de seu lucro líquido entre os anos de 2010 e 2019 foi de aproximadamente 7,92\% a.a, enquanto seus ativos cresceram a uma taxa média de $15,43 \%$ a.a nesse mesmo período, fazendo com que o seu ROA fosse reduzindo ao passar do tempo.

Já no caso do Banco do Brasil, seu lucro líquido cresceu a uma taxa média de $5,16 \%$ a.a nesse período analisado, enquanto seus ativos aumentaram a uma taxa de $8,15 \%$ a.a, ocasionando a redução gradual de sua rentabilidade.

Ao estudar o ano de 2020, é possível notar uma notável similaridade de resultados entre as instituições estudadas, tendo uma clara redução do ROA. Essa redução generalizada da rentabilidade foi ocasionada principalmente pela queda dos lucros nesse ano, acompanhada pelo aumento dos ativos totais de cada empresas.

\subsection{Margens}

No que tange a margem líquida, pode-se observar uma alta similaridade de resultados. No gráfico 7 é possível visualizar as mudanças na média das margens: 


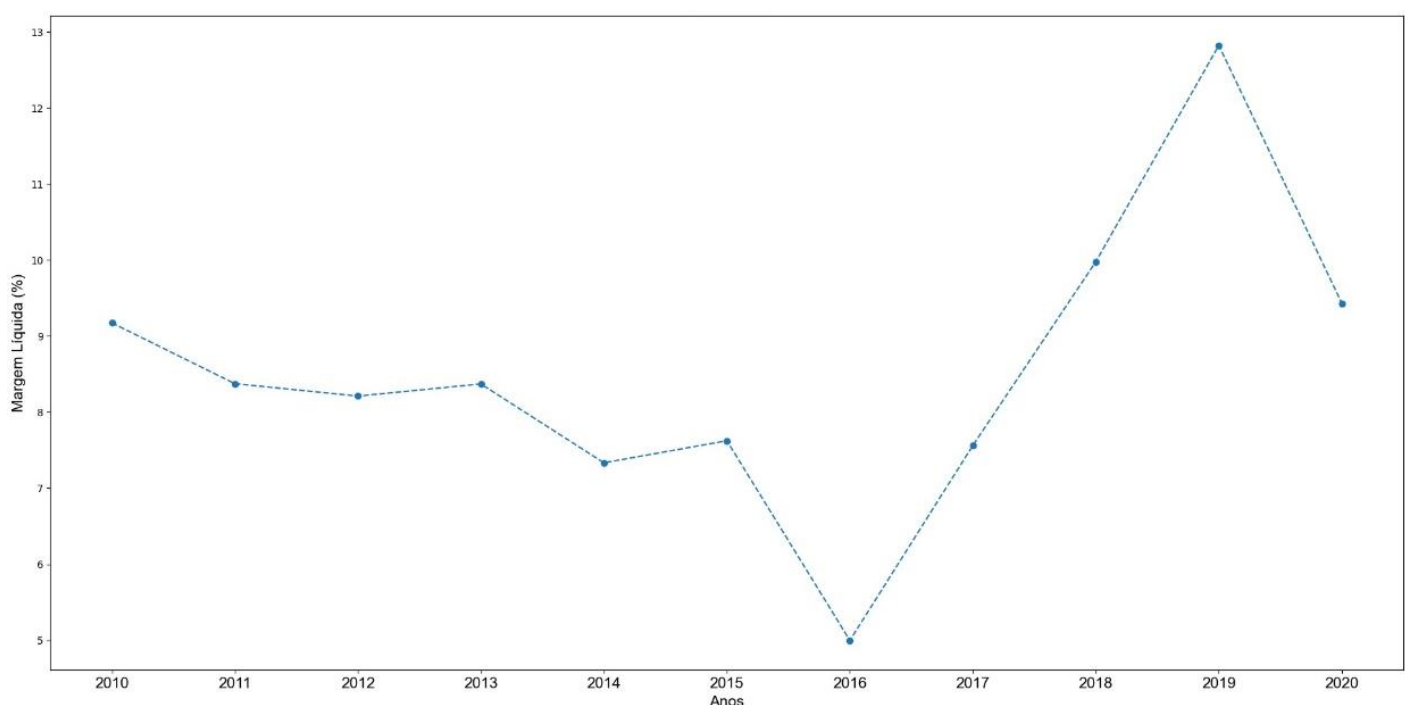

Gráfico 7 - Evolução da margem líquida média Fonte: Elaborado pelo autor, 2021.

Analisando a movimentação desse indicador, é possível concluir que os bancos acabaram elevando sua margem de lucratividade durante os anos da amostra. Assim como no indicador anterior, a margem líquida se deteriorou levemente até atingir seu valor mínimo em 2016.

A partir desse ano, o indicador passou por uma correção positiva, chegando ao seu pico no ano de 2019, tendo assim um aumento acumulado de aproximadamente $39,78 \%$ desde 2010 .

Por mais que o ano de 2020 tenha sido um ano de reduções na lucratividade, as margens líquidas, na média, passaram por um movimento de apreciação no longo prazo.

Ao comparar o gráfico 2 com o gráfico 8 a seguir, é possível observar que os lucros líquidos, na média, vêm apresentando uma taxa de crescimento maior do que as receitas totais geradas, essas que consideram tanto as receitas provenientes da intermediação financeira quanto as demais receitas operacionais, como taxas e serviços. Esse crescimento mais intenso dos lucros faz com que justamente a margem líquida se aprecie ao longo dos anos. 


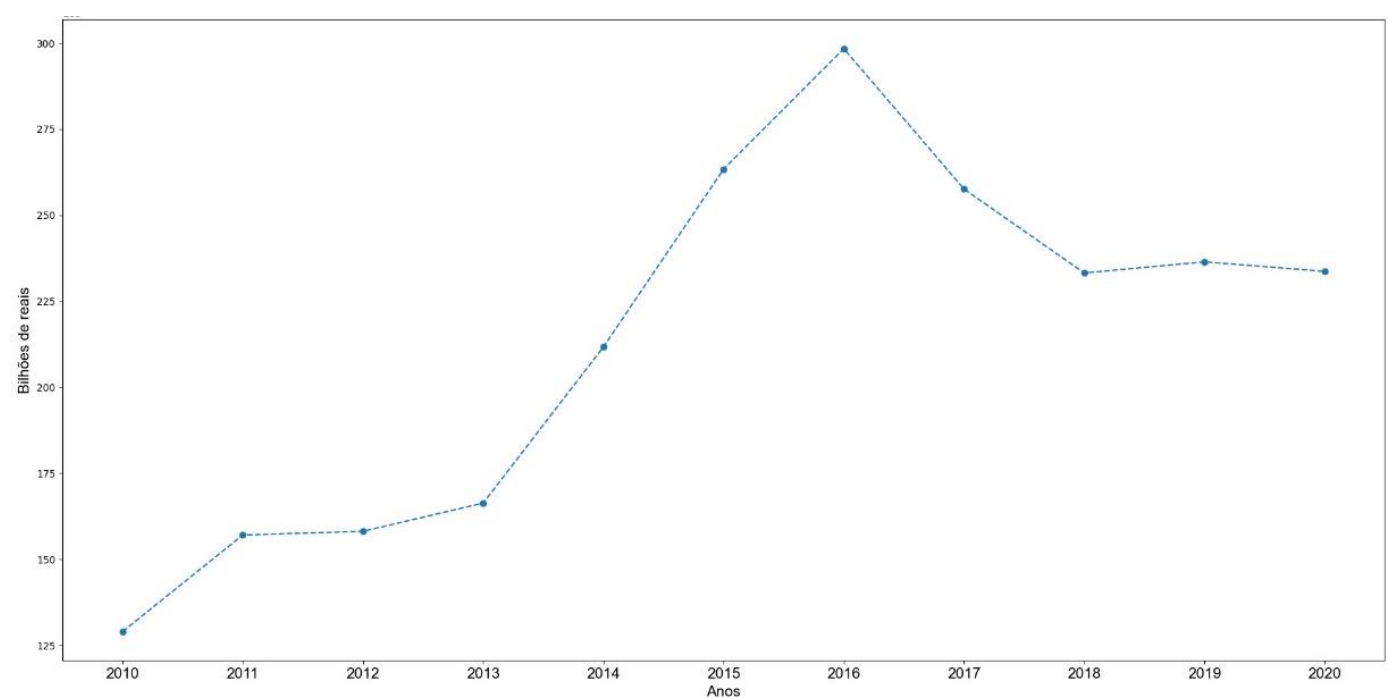

Gráfico 8 - Evolução da receita total média Fonte: Elaborado pelo autor, 2021.

No gráfico 9, a média da margem líquida dos players estudados é detalhada de forma a destacar o resultado individual de cada banco presente no estudo:

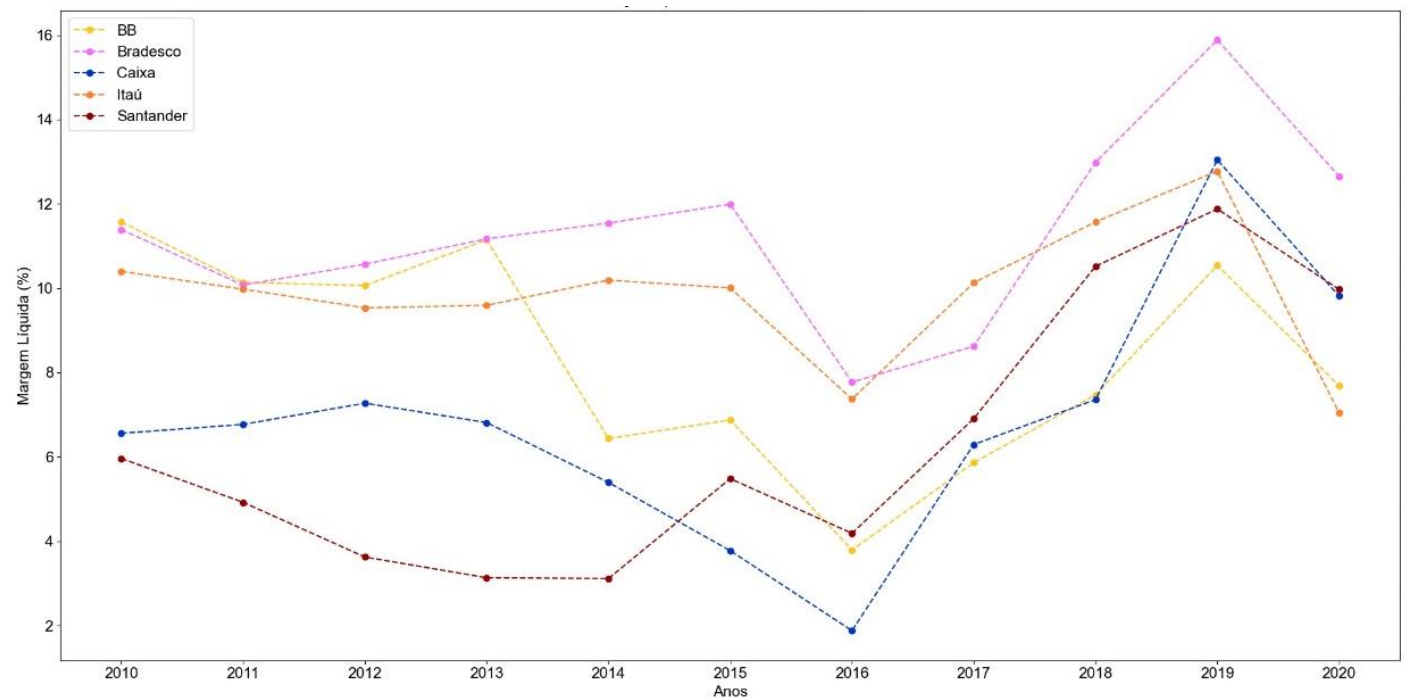

Gráfico 9 - Evolução da margem líquida estratificada por instituição Fonte: Elaborado pelo autor, 2021.

Até o ano de 2016, todas as instituições apresentaram quedas graduais em suas margens, revertendo em altas constantes até o ano de 2019. Ao chegar nesse ano, todos os bancos analisados apresentaram um resultado positivo nesse indicador, com exceção do Banco do Brasil que teve uma queda de 8,87\% acumuladamente.

No entanto, vale destacar que, assim como foi citado na análise do ROA, essa redução da margem não foi ocasionada por redução de lucros. Isso pode ser explicado pelo fato da receita total do Banco do Brasil ter crescido mais rapidamente do que seus lucros, fazendo com que a margem líquida reduza ao 
passar dos anos. No gráfico 10 fica exposto a evolução das receitas totais dos bancos analisados:

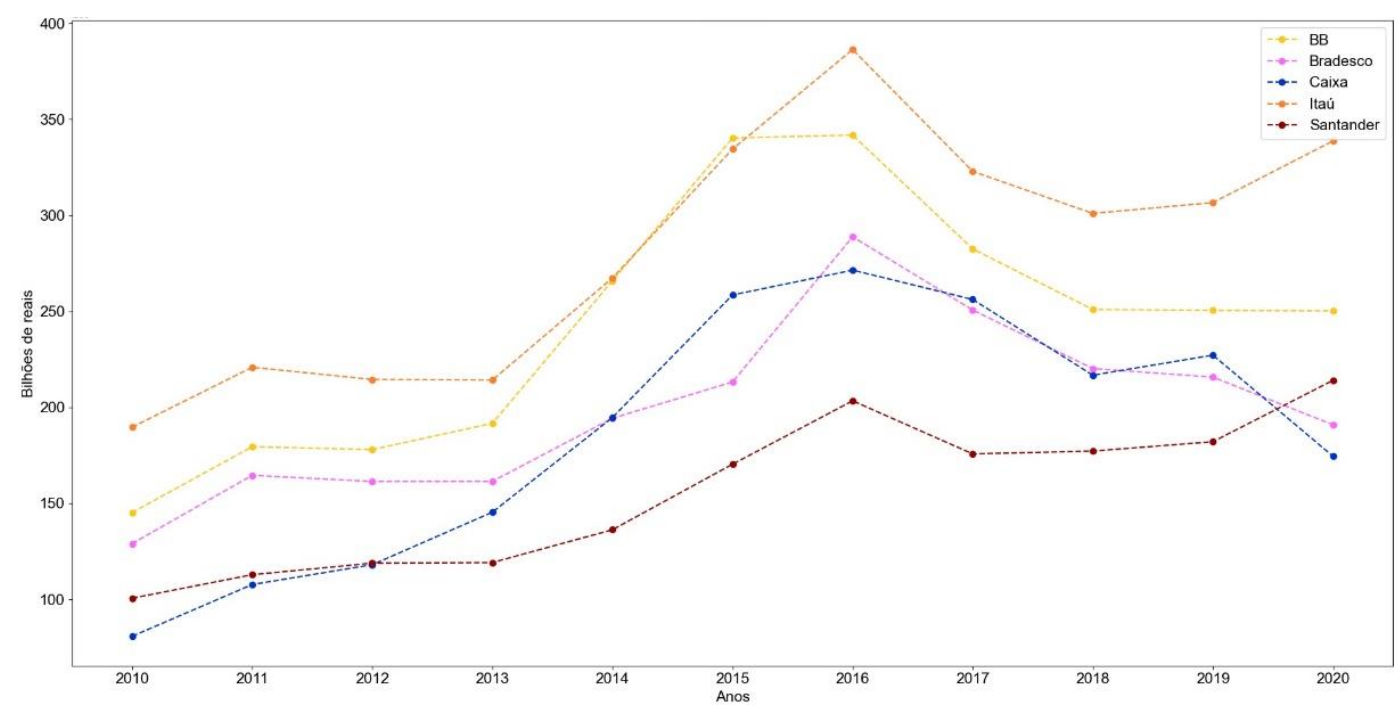

Gráfico 10 - Evolução da receita total estratificada por instituição Fonte: Elaborado pelo autor, 2021.

A variação composta do lucro líquido dessa instituição foi, em média, de $5,16 \%$ a.a, enquanto sua receita total nesse mesmo período cresceu $6,25 \%$ a.a, ocasionando essa redução gradual.

Assim como ocorreu com o ROA, a margem líquida em 2020 apresentou uma clara redução para todas as instituições analisadas. Isso acaba sendo explicado pelo fato de que o lucro líquido passou por uma queda muito maior do que a receita gerada no ano, demonstrando um aumento significativo nas despesas totais delas.

No entanto, por mais que o ano de 2020 tenha sido marcado por reduções de lucros, a maior parte dos bancos estudados apresentaram um aumento de suas margens líquidas quando comparadas desde o ano de 2010.

\subsection{Liquidez Imediata}

Analisando a liquidez imediata das instituições selecionadas, as empresas acabaram possuindo uma certa correlação de resultados, mesmo que menos visível em comparação com os demais indicadores expostos. A evolução da liquidez média pode ser vista no gráfico 11: 


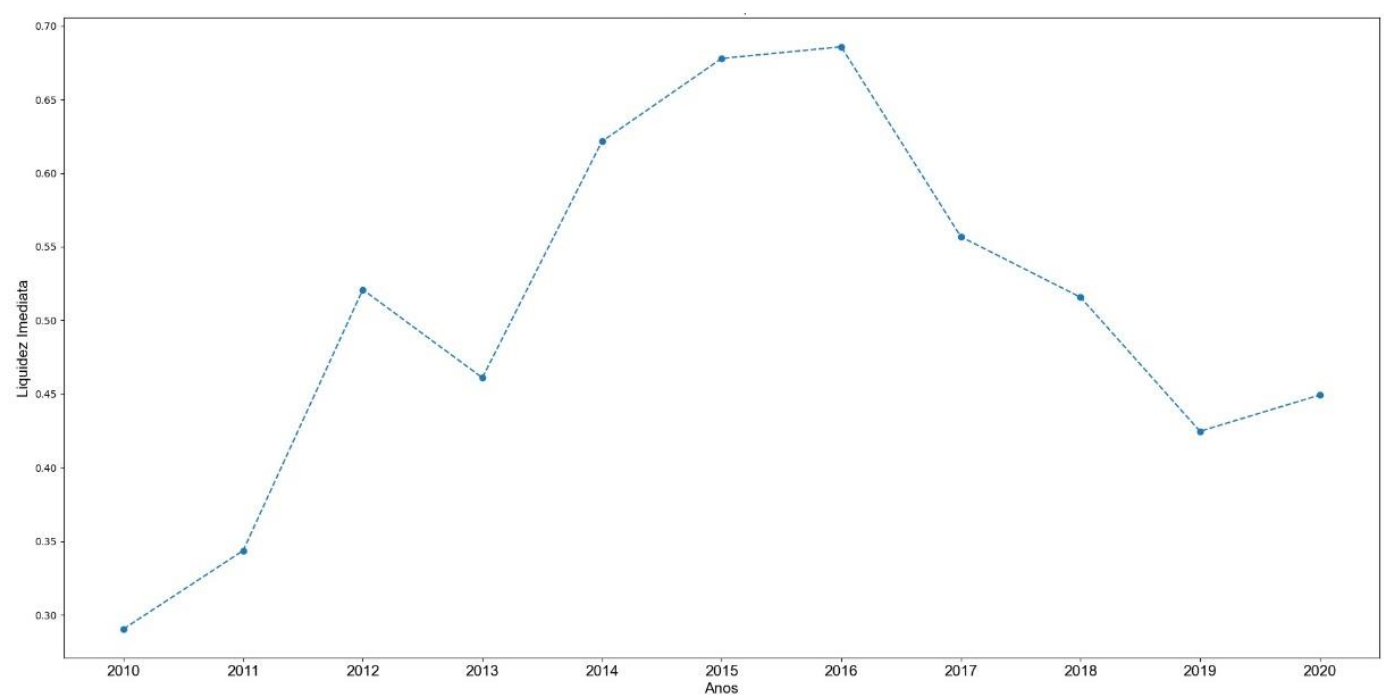

Gráfico 11 - Evolução da liquidez imediata média Fonte: Elaborado pelo autor, 2021.

Sob o ponto de vista macro, os players analisados acabaram, na média, aumentando os seus níveis de liquidez imediata nos últimos anos. É notável que esse índice passou por um período de elevação até o ano de 2016, sendo justificado principalmente pela elevação dos ativos de alta liquidez, que pode ser visto no gráfico 12.

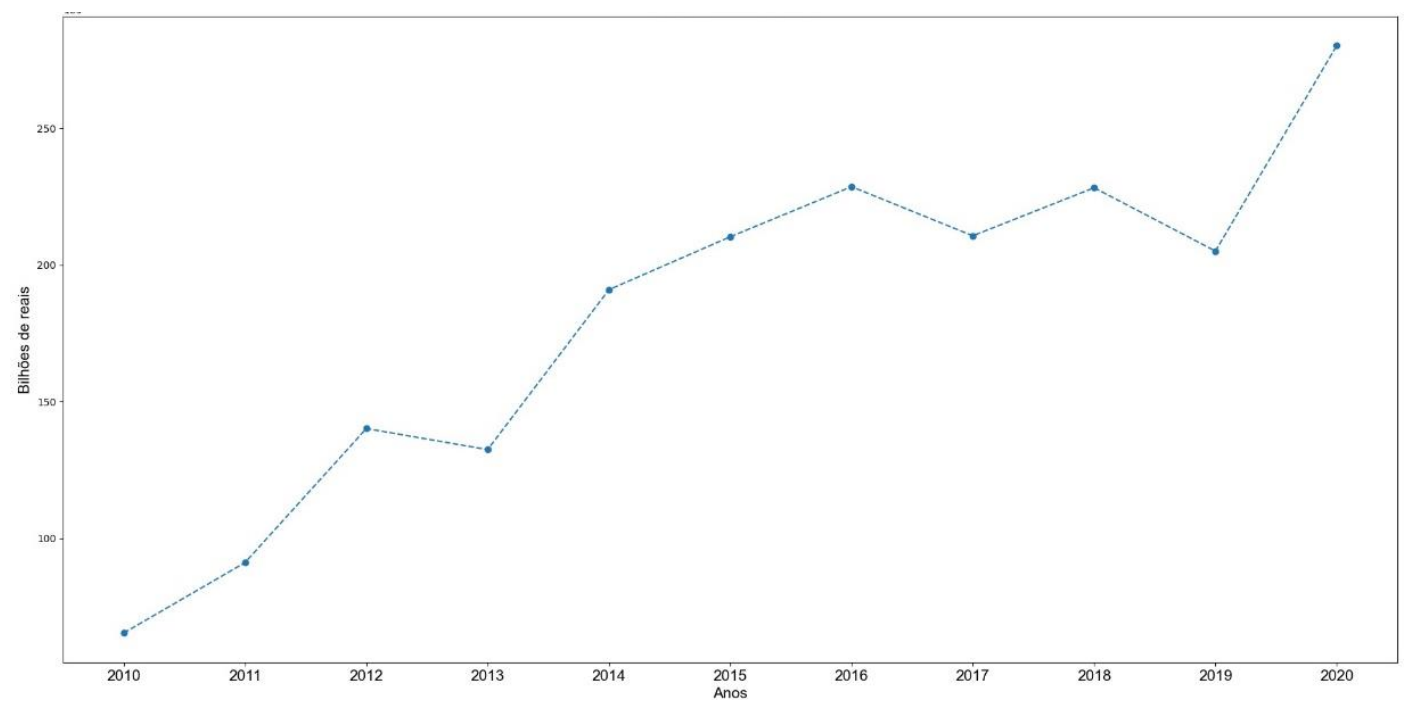

Gráfico 12 - Evolução do ativo circulante médio Fonte: Elaborado pelo autor, 2021.

Depois desse ano, a média desse índice passou por um período de encolhimento, sendo caracterizado tanto pelo movimento de redução dos ativos de alta liquidez, mas também pela contínua elevação dos passivos circulantes, o que intensifica ainda mais a redução do índice. Esse aumento contínuo dos passivos circulantes está exposto no gráfico 13 a seguir: 


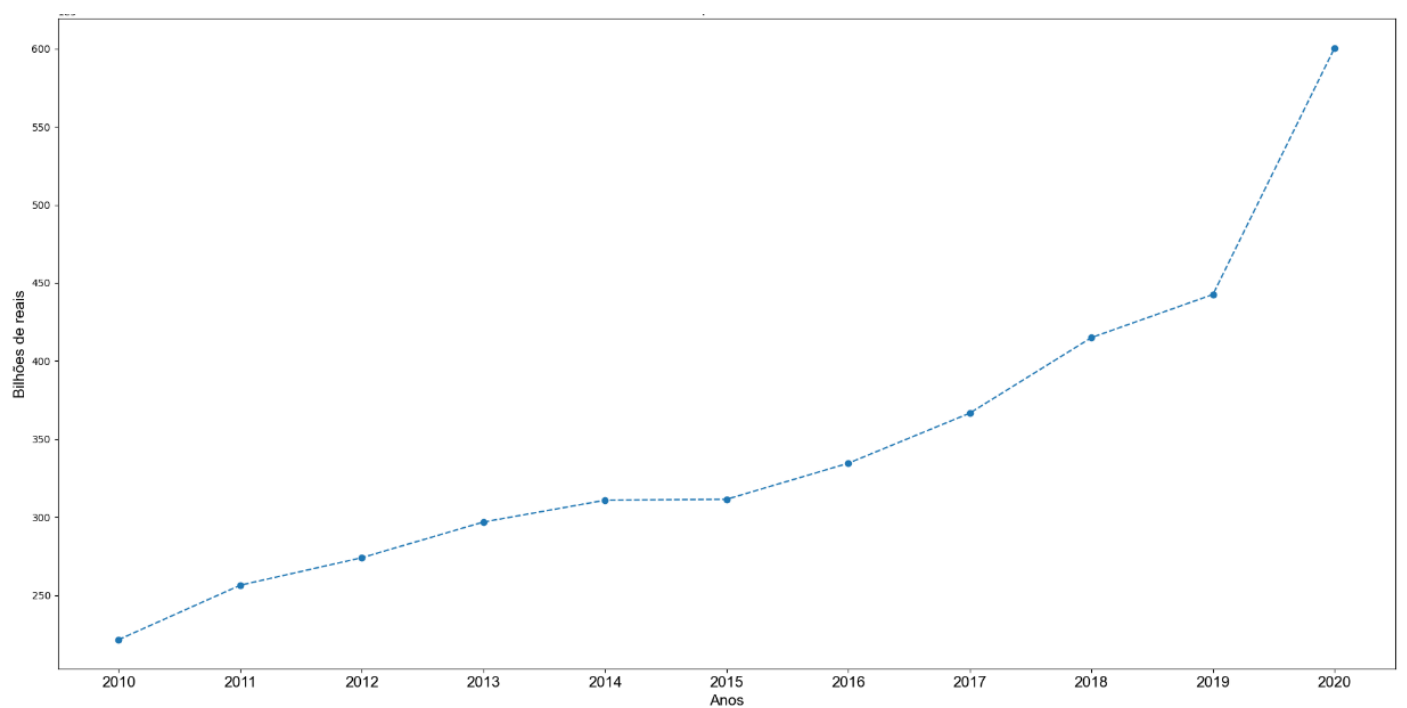

Gráfico 13 - Evolução do passivo circulante médio Fonte: Elaborado pelo autor, 2021.

Para entender melhor a movimentação da média desse indicador, o gráfico 14 expõe a evolução da liquidez imediata para cada empresa estudada:

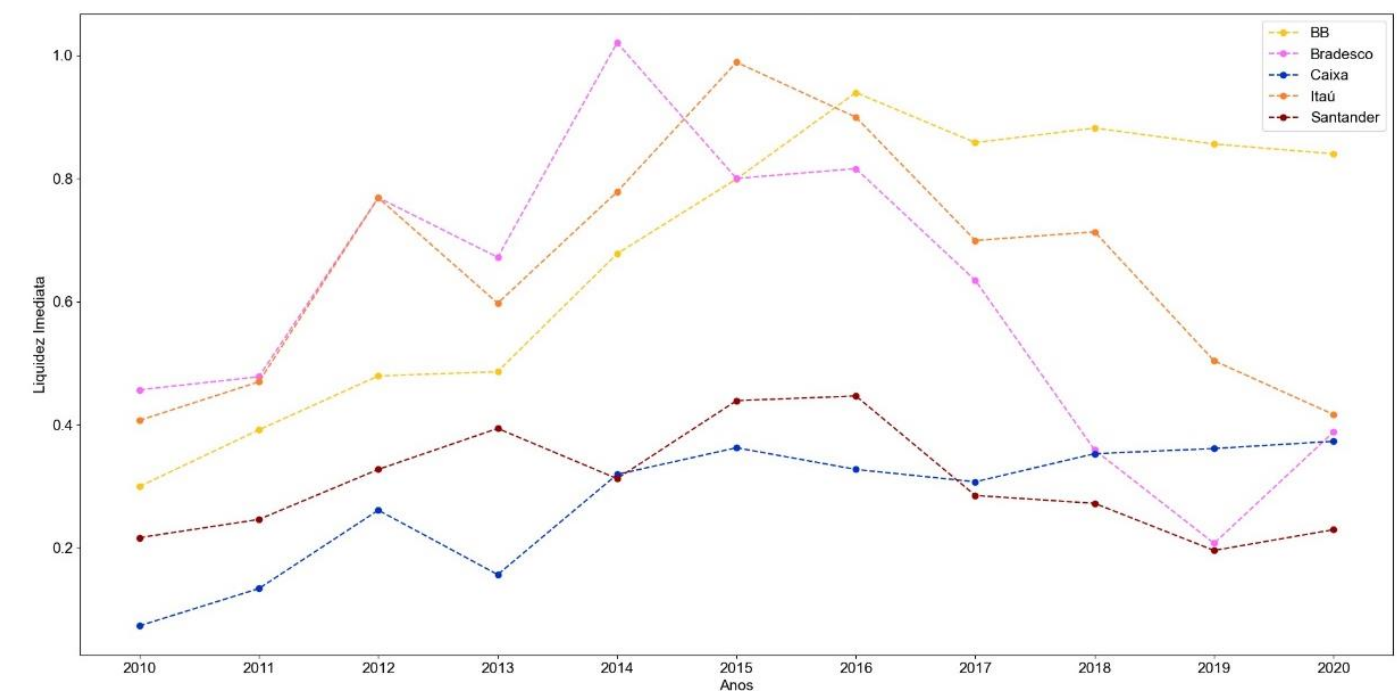

Gráfico 14 - Evolução da liquidez imediata estratificada por instituição Fonte: Elaborado pelo autor, 2021.

Quase a totalidade das empresas da amostra acabaram apresentando uma elevação de sua liquidez imediata, tendo como destaque a Caixa Econômica Federal e o Banco do Brasil, que apresentaram um aumento acumulado até 2020 de $411,11 \%$ e 180,54\% respectivamente.

O único banco que apresentou uma queda em sua liquidez foi o Bradesco. Esse movimento foi justificado pela redução de seus ativos de liquidez ao longo dos anos, principalmente entre os anos de 2015 e 2019. Essa movimentação dos ativos é evidenciada no gráfico 15 : 


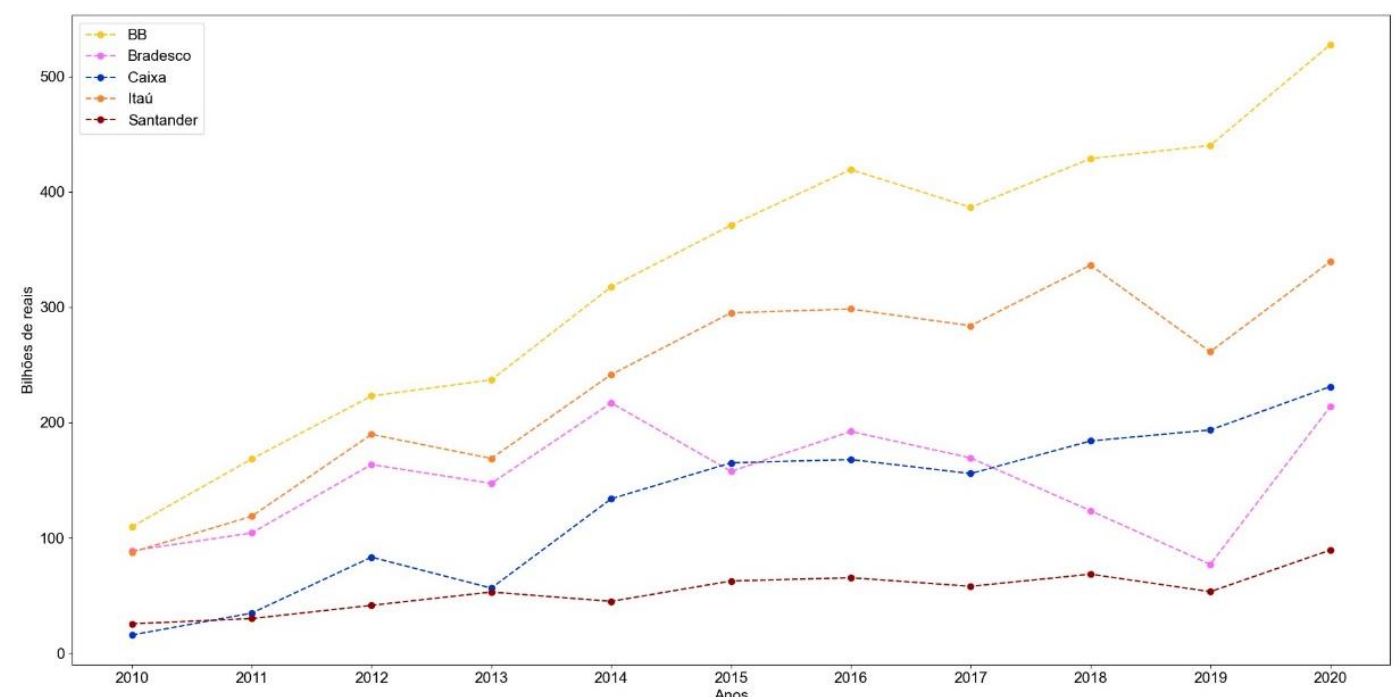

Gráfico 15 - Evolução do ativo circulante estratificado Fonte: Elaborado pelo autor, 2021.

Concomitante a essa redução de ativos, o Bradesco vem aumentando constantemente seus passivos de curto prazo, tendo uma taxa de crescimento média de $7,47 \%$ a.a até 2019 , intensificando ainda mais a redução de sua liquidez imediata ao longo do tempo. No gráfico 16 é possível visualizar a evolução dos passivos circulantes de cada instituição:

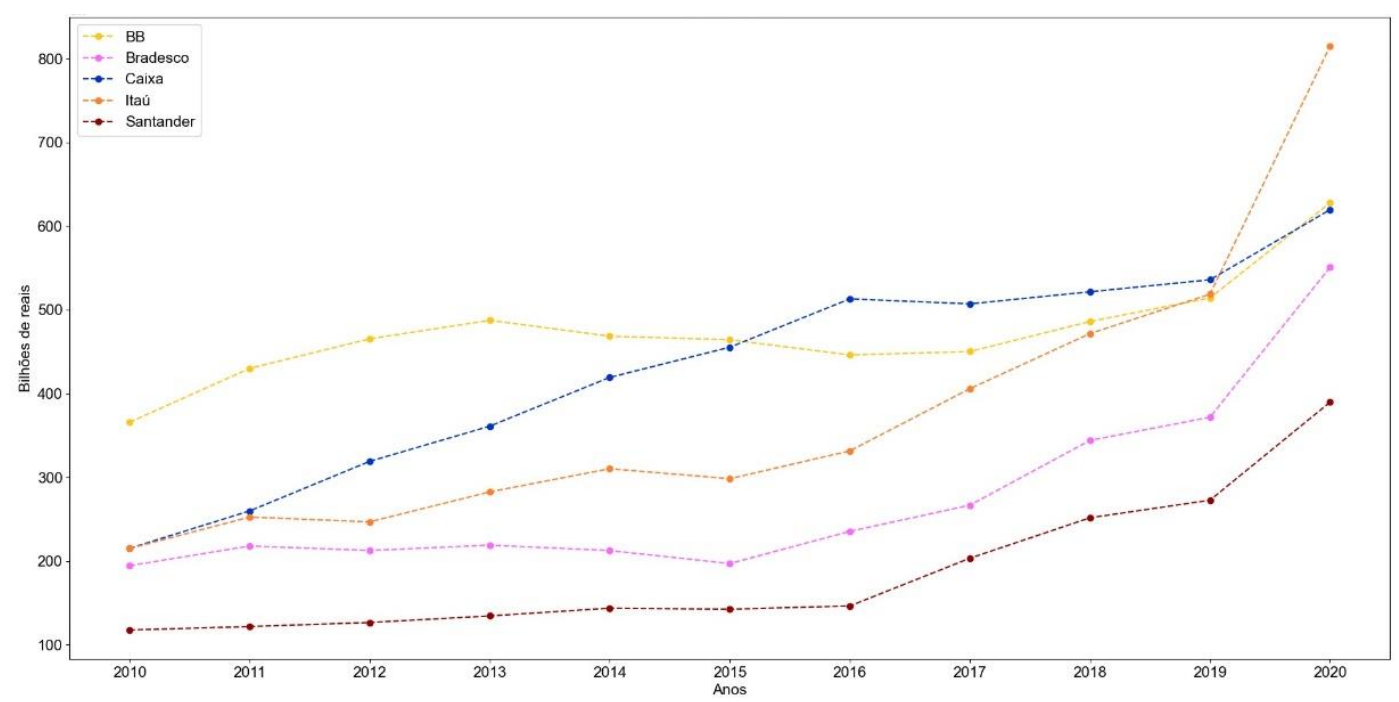

Gráfico 16 - Evolução do passivo circulante estratificado Fonte: Elaborado pelo autor, 2021.

Por mais que o ano de 2020 tenha ocasionado uma piora nos indicadores financeiros dos bancos analisados, isso acabou não ocorrendo para a liquidez imediata. Das 5 empresas estudadas, 3 tiveram um aumento de sua liquidez de curto prazo no respectivo ano, sendo elas o Bradesco, Santander e Caixa Econômica Federal.

Para todas as empresas analisadas, tanto os ativos quanto os passivos circulantes aumentaram em 2020. No entanto, para as 3 empresas citadas, os 
ativos acabaram tendo um aumento percentual maior do que seus passivos, elevando assim a liquidez imediata, enquanto o Banco do Brasil e o Itaú passaram pelo movimento contrário.

\section{4 Índice de Basileia}

Diferentemente dos demais indicadores, o índice de Basileia apresentou uma menor correlação entre as instituições. No gráfico 17 é exposto as mudanças na média do referido índice das instituições durante os anos analisados:

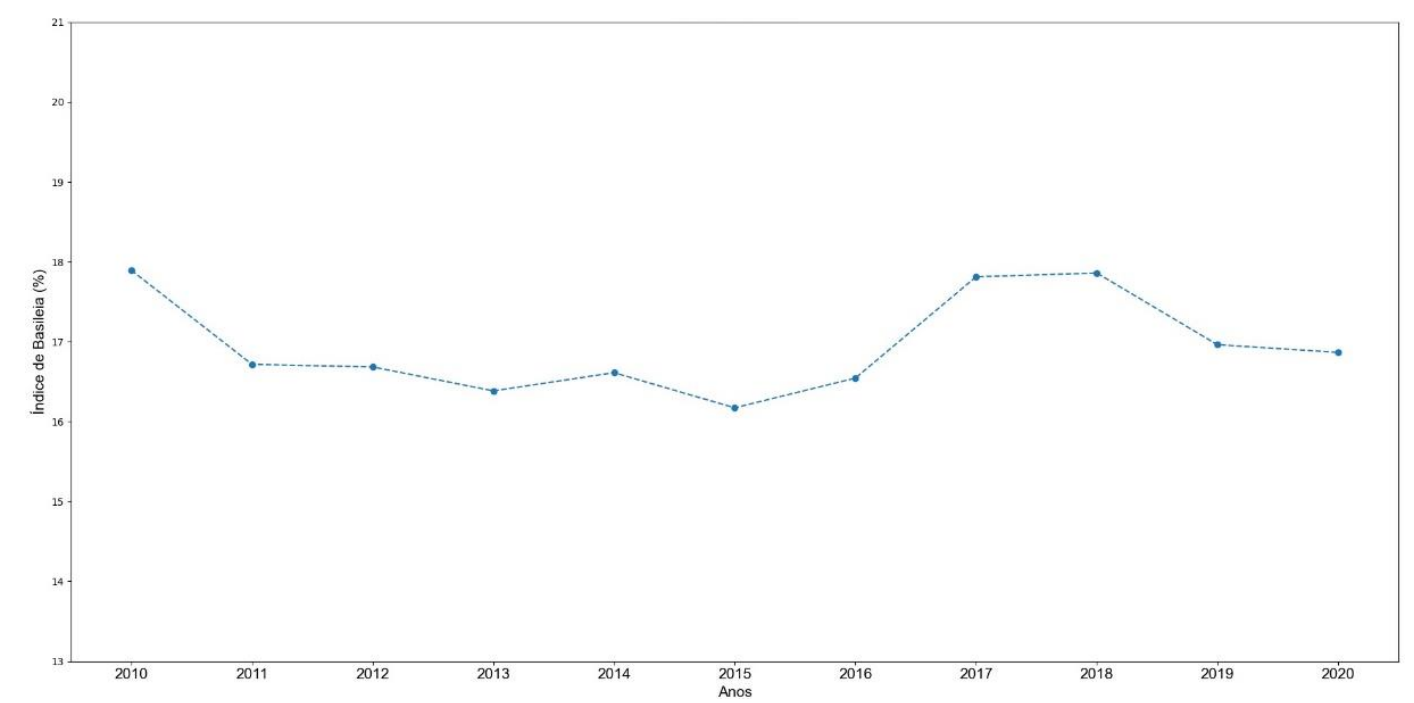

Gráfico 17 - Evolução do índice de Basileia médio Fonte: Elaborado pelo autor, 2021.

Ao comparar com as análises feitas até então, é possível observar que esse indicador é o que mais se manteve estável com o passar dos anos. A média desse índice acabou passando por uma redução acumulada de aproximadamente $5,74 \%$, dando assim uma diminuição média composta de $0,59 \%$ a.a.

Com o intuito de entender melhor a movimentação desse índice entre as instituições, o gráfico 18 demonstra como esse indicador se comportou para cada empresa estudada: 


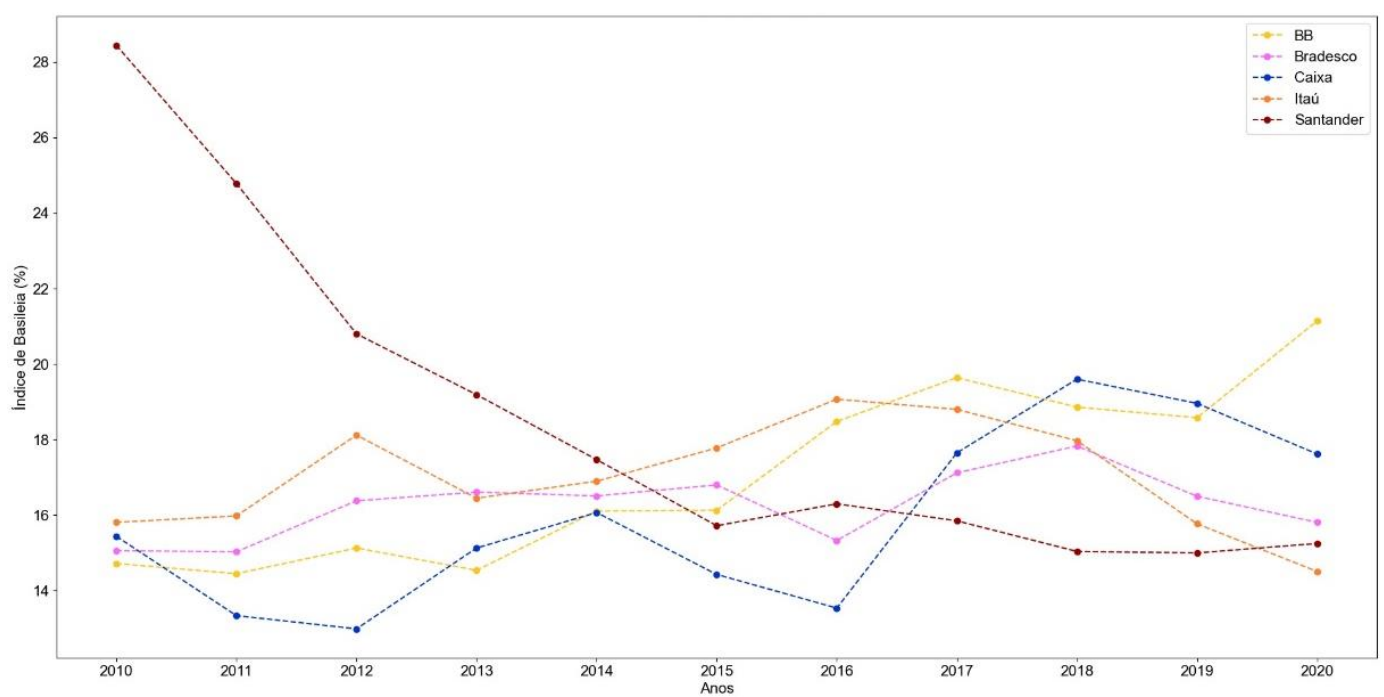

Gráfico 18 - Evolução do índice de Basileia estratificado Fonte: Elaborado pelo autor, 2021.

O maior destaque certamente é a evolução do índice por parte do Santander, que apresentou uma redução de 46,38\% entre os anos de 2010 e 2020. Durante esse período, por conta da diminuição desse índice, o banco acabou se alavancando mais e reduziu seu posicionamento conservador, o que acaba servindo como base para o bom desempenho que esse banco teve nos demais indicadores anteriores quando comparado com seus pares de mercado.

Além disso, outros destaques foram o Banco do Brasil e a Caixa Econômica Federal, esses que elevaram os seus índices em 26,22\% e 22,80\% respectivamente entre os anos. Porém, de forma geral, não houve mudanças significativas e generalizadas entre todos os bancos analisados. 


\section{5 Índice de imobilização}

Ao olhar o índice de imobilização, é possível visualizar uma alta correlação entre os dados das instituições analisada. A evolução da média desse indicador é exposta no gráfico 19:

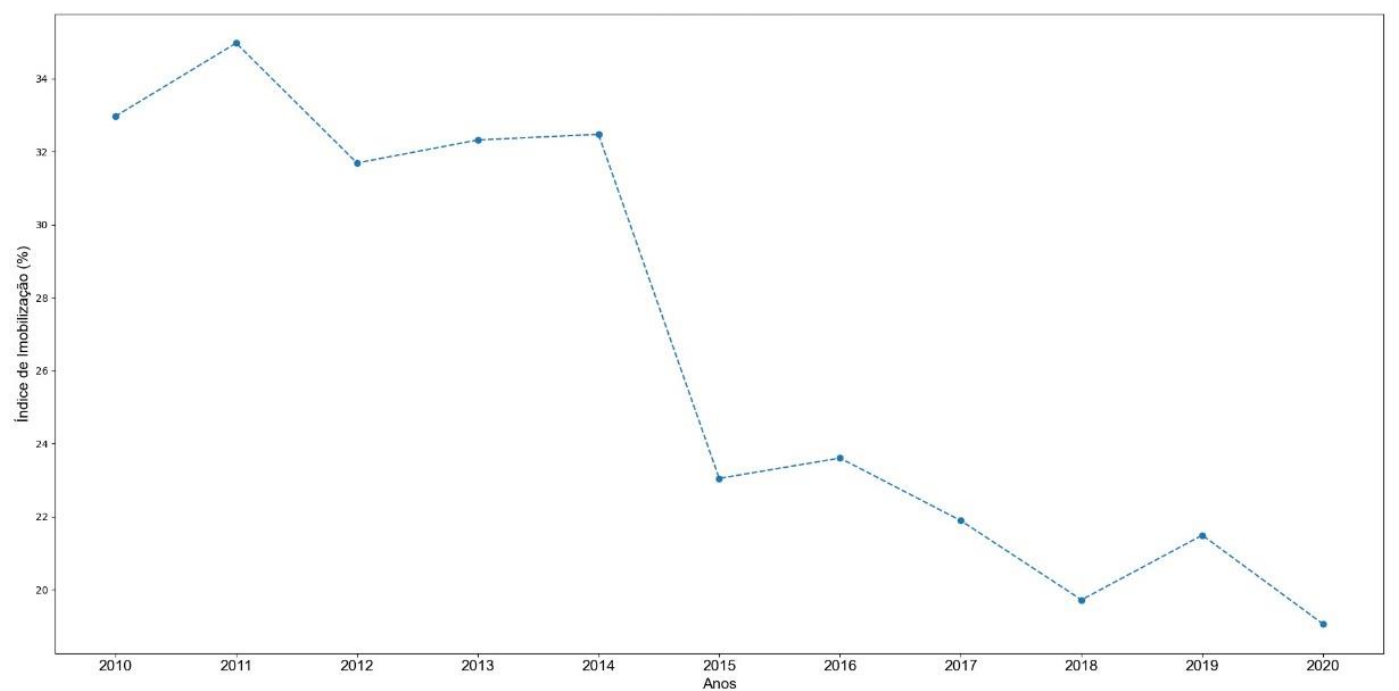

Gráfico 19 - Evolução do índice de imobilização médio Fonte: Elaborado pelo autor, 2021.

Tendo em vista o gráfico exposto, é evidente uma forte redução desse índice nos últimos anos, principalmente a partir de 2014. Isso mostra que, na média, as instituições do estudo têm tomado a decisão de reduzir a quantidade de estabelecimentos físicos e de imóveis de uma forma geral, procurando assim trabalhar em uma estrutura mais enxuta e, por consequência, menos custosa.

Já no gráfico 20 a seguir, a média do índice é estratificada para tornar possível a visualização da situação de cada banco: 


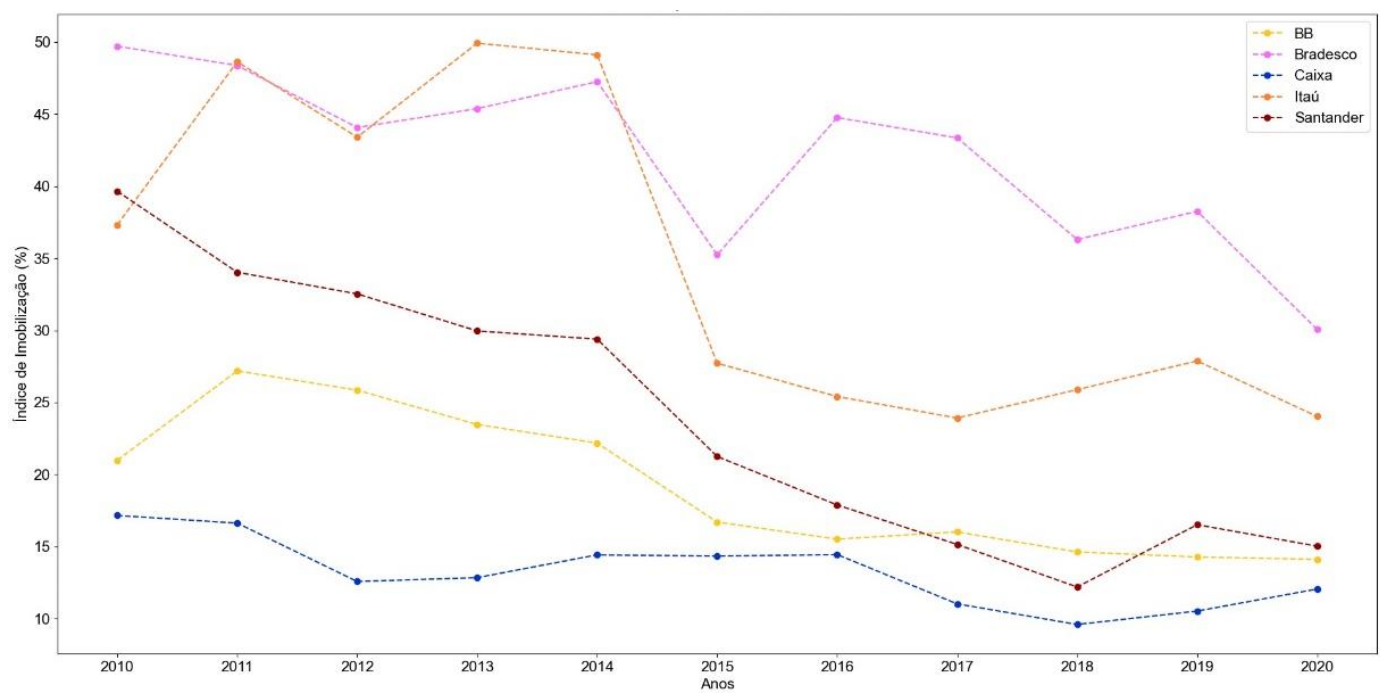

Gráfico 20 - Evolução do índice de imobilização estratificado Fonte: Elaborado pelo autor, 2021.

Assim como é mostrado no gráfico, todas as empresas acabaram reduzindo os seus respectivos índices de imobilização. Assim como foi dito para o índice de Basileia, o Santander acabou se destoando de seus competidores, tendo assim a maior redução percentual entre todos os players em questão.

Essa redução de ativos imobilizados do banco pode ter dado ainda mais espaço para que ele pudesse otimizar gastos, já que a quantidade de ativos imobilizados reduziu e as despesas provenientes deles, impulsionando os destaques nos demais indicadores financeiros estudados.

Essa movimentação de redução de ativos imobilizados, por mais que tenha sido mais intensamente utilizado pelo Santander, tem sido intensificada ano após ano por todos os players estudados. Outras duas instituições que se destacaram nessa movimentação de redução de ativos foram o Itaú e o Bradesco, que reduziram seus índices de imobilização em aproximadamente $35,61 \%$ e $39,51 \%$ entre os anos de 2010 e 2020. 


\section{Conclusão}

O presente estudo teve como objetivo estudar a evolução da saúde financeira dos 5 maiores conglomerados bancários brasileiros durante um contexto de grandes inovações e mudanças no ambiente competitivo.

Para atingir esse objetivo, foram coletados os demonstrativos financeiros, sendo eles o balanço patrimonial e a demonstração de resultado do exercício, das 5 maiores instituições financeiras em quantidade de ativos entre os anos de 2010 e 2020. Depois disso, foram calculados os indicadores financeiros para cada ano, para depois serem feitas as comparações e análises. Para realizar essas análises, foram criados gráficos desses indicadores e das variáveis que impactam os mesmos, procurando assim compreender o que ocasionou cada mudança.

No quesito de rentabilidade, foi possível concluir que a maior parte das instituições apresentaram um aumento de seus ROAs até o ano de 2019. Vale destacar que as duas únicas instituições que perderam rentabilidade não reduziram por conta de possíveis perdas de lucros, mas sim porque cresceram mais intensamente seus ativos em relação aos seus lucros líquidos. Já no ano de 2020, período marcado pelo início da pandemia de Covid-19, os lucros líquidos das empresas caíram de forma generalizada e os ativos mantiveram seu crescimento, fazendo com que as rentabilidades fossem reduzidas. No entanto, de forma geral, os bancos obtiveram um bom desempenho nesse indicador.

Ao estudar as margens líquidas, é notável a capacidade dos bancos em conseguir elevar suas margens durante o período analisado. Até o ano de 2019, quase a totalidade dos bancos aumentaram suas margens, tendo como única exceção o Banco do Brasil. Esse resultado acaba sendo explicado pelo fato de que essas instituições cresceram os seus lucros mais intensamente do que suas receitas geradas. Mesmo com a pandemia no ano de 2020, a maioria das instituições tiveram uma variação positiva de suas margens quando comparadas com as margens em 2010. A instituição que teve maior destaque nesse indicador foi o Santander, que cresceu mais rapidamente suas margens em comparação com seus pares e apresentou a menor queda percentual no ano de 2020. Assim 
como foi dito para o ROA, as instituições analisadas também tiveram uma boa performance nesse indicador financeiro.

Já para a liquidez imediata, a maioria das empresas também apresentaram um resultado positivo no período mensurado. Todas as instituições passaram por um aumento de liquidez imediata, exceto o Bradesco. Esse aumento se deu pela maior intensidade do aumento dos ativos do que dos passivos, enquanto 0 Bradesco acabou apresentando uma redução de seus ativos até o ano de 2019. Por mais que o ano de 2020 tenha sido marcado por uma elevação muito forte dos ativos desse banco, ele acabou apresentando uma variação acumulada negativa em sua liquidez. Porém, na média, os players analisados conseguiram controlar esse índice de liquidez.

Por último, sob a ótica do índice de Basileia, os grandes bancos também controlaram o seu nível de alavancagem estudado no índice de Basileia. A maior parte das instituições apresentaram uma elevação de seus índices, exceto o Santander. No caso dessa empresa, ela apresentou uma redução muito significativa de seu índice, o que acaba colaborando para os destaques positivos que ela obteve nos demais indicadores em relação aos seus pares, usando sua alavancagem financeira para obter esses resultados. No entanto, os bancos de forma geral se mantiveram relativamente estáveis nesse indicador.

Conclui-se que a narrativa apresentada inicialmente de que os bancos têm sido ameaçados financeiramente pelas grandes ondas de inovação, como fintechs e criptomoedas, não pode ser observada no período analisado. Ao analisar os dados históricos entre 2010 e 2020 desses indicadores financeiros, é possível observar não apenas um controle dos indicadores, mas também uma certa melhora deles.

Com isso, é notável uma alta capacidade dos bancos em absorverem e se adaptarem financeiramente às mudanças em seu ambiente competitivo. Essa alta capacidade certamente será extremamente importante para que essas instituições possam se permanecer em um ambiente altamente competitivo.

Como sugestão para estudos futuros, seria interessante observar se os bancos de médio e pequeno porte teriam essa capacidade de adaptação em sua saúde financeira ou não. 


\section{Referências Bibliográficas}

BANCO CENTRAL. O que é banco (instituição financeira). [S. I.], Jan./Dez. [201-?]. Disponível em:

https://www.bcb.gov.br/estabilidadefinanceira/bancoscaixaseconomicas. Acesso em: 23 jun. 2021.

BC. Recomendações de Basileia. [S. I.], 2021. Disponível em: https://www.bcb.gov.br/estabilidadefinanceira/recomendacoesbasileia. Acesso em: 30 out. 2021.

BRONZATI, Aline. Ativos de bancos somam R\$ 7,4 trilhões e superam PIB. [S. I.], 25 maio 2020.2 Disponível em: https://economia.uol.com.br/noticias/estadao-conteudo/2020/05/25/ativos-debancos-somam-r-74-trilhoes-e-superam-pib.htm. Acesso em: 5 maio 2021.

BRONZATI, Aline. Transformação digital do setor bancário 'nos angustia toda noite', diz Setubal, do Itaú. [S. I.], 3 set. 2019. Disponível em: https://economia.estadao.com.br/noticias/negocios,transformacao-com-fintechsnos-angustia-toda-noite-diz-setubal,70002995258. Acesso em: 5 maio 2021.

CONSUMIDOR MODERNO. A evolução das fintechs no Brasil: elas ganham cada vez mais espaço. [S. I.], 15 fev. 2021. Disponível em:

https://www.consumidormoderno.com.br/2021/02/15/evolucao-fintechs-brasilganham-mais-espaco/. Acesso em: 23 jun. 2021.

DRSKA, Moacir. Bancos versus fintechs: muito barulho por nada? Os gigantes respondem. [S. I.], 24 ago. 2020. Disponível em:

https://neofeed.com.br/blog/home/bancos-versus-fintechs-muito-barulho-pornada-os-gigantes-respondem/. Acesso em: 5 maio 2021.

ESTEVEZ , Eric. Financial Technology - Fintech. [S. I.], 28 ago. 2020. Disponível em: https://www.investopedia.com/terms/f/fintech.asp. Acesso em: 5 maio 2021.

FIDELITY DIGITAL ASSETS. Fidelity Digital Assets' 2021 Institucional Investor Digital Assets Study. [S. I.], 20 jul. 2021. Disponível em: https://www.fidelitydigitalassets.com/articles/digital-asset-survey-2021. Acesso em: 10 out. 2021.

IF.DATA. Dados Selecionados. [S. I.], Jan./Dez. [201-?]. Disponível em: https://www3.bcb.gov.br/ifdata/index.html. Acesso em: 23 jun. 2021.

JUNIOR, Humberto Maia. A guerra entre os bancos tradicionais e as fintechs se acirra. [S. I.], 9 out. 2020. Disponível em: 
https://veja.abril.com.br/economia/a-guerra-entre-os-bancos-tradicionais-e-asfintechs-se-acirra/. Acesso em: 5 maio 2021.

REIS, Tiago. Market Share: entenda o conceito e como aplicá-lo em sua empresa. [S. I.], 4 jun. 2018. Disponível em:

https://www.suno.com.br/artigos/market-share/. Acesso em: 23 jun. 2021.

ROSS, Stephan et al.. Administração Financeira. 10. ed. [S. I.: s. n.], AMGH Editora Ltda, 2015.

RUBINSTEINN, Gabriel. $70 \%$ dos investidores institucionais querem ter exposição às criptomoedas. [S. I.], 21 jul. 2021. Disponível em: https://exame.com/future-of-money/dinheiro-tendencias/70-dos-investidoresinstitucionais-querem-ter-exposicao-as-criptomoedas/. Acesso em: 10 out. 2021.

SISTEMA Financeiro Nacional (SFN). [S. I.], Jan./Dez. [21--?]. Disponível em: https://www.bcb.gov.br/estabilidadefinanceira/sfn. Acesso em: 5 maio 2021.

WALDEN, Stephanie. What Is Fintech And How Does It Affect How I Bank? [S. I.], 3 ago. 2020. Disponível em: https://www.forbes.com/advisor/banking/whatis-fintech/. Acesso em: 23 jun. 2021.

WARREN Buffett | Lecture | University Of Nebraska | 2003. [S. I.: s. n.], 2020. Disponível em: https://www.youtube.com/watch?v=N1t3pVjvRjc. Acesso em: 2 nov. 2021.

VILLAÇA, Maria José. O conceito de liquidez. Revista de Administração de Empresas, [S. I.], p. 1-1, 2 jul. 2015. Disponível em: https://www.scielo.br/j/rae/a/YCZzCbcz679XHqG65d4hwfh/?lang=pt\#. Acesso em: 30 out. 2021. 